DOI: $10.2478 / \mathrm{v} 10141-010-0007-\mathrm{z}$

\title{
University Sports: Major Development and New Perspectives
}

\author{
Otmar Weiss
}

Institut für Sportwissenschaft der Universität Wien, Austria

ABSTRACT

New technologies, scientific findings and new or refined kinds of sport as well as national and international contests determine the image of university sports. There is no doubt that university sports are a growing area and will play an important role in the future. Their significance will increase in particular with the increase of knowledge about the positive effects of sports.

Looking at social development as a whole and in its parts makes it possible to identify university sports in their present state, their dynamics and development within a context. By way of example major trends and prospects of university sports in contemporary societies will be discussed. In addition some data from empirical studies will be presented in order to underline the argumentation.

KEYWORDS university sports, trends, functions, identity

Although nowadays university sports play a very important role worldwide, for historical reasons some universities or parts of the scientific community still have certain prejudices against sport in general. There is a saying that brain and brawn stand in inverse proportion to one another. And indeed some suggest that too much muscle is detrimental to mental powers!

However, these prejudices are disappearing with the growing scientific knowledge about the positive effects of sport. The foundation and rapid development of the new scientific discipline "Sport Science" in the past century have not only contributed strongly towards the positive image of sport but have also helped to overcome irrational attitudes concerning sport. Sport scientists have gained valuable knowledge about the important role of sport in modern societies and identified the social significance of sport in many respects. At the University of Vienna right now we are conducting a project aimed at designing a sport index. Much as in the PISA study, in this project the significance of sport in different European countries will be determined and compared. One adequate indicator among others - will be university sports. 
In other studies it has been shown that sport is taking on serious functions in many circles within modern society, this being especially true for university sports. For instance there is the development of the:

\section{Integration function}

Due to the European integration process the integration function of sport is becoming more and more vital in present-day society. In Europe, with its ethnically and culturally diverse populations, the role of sport for cultural dialogue is of particular interest.

Sport is considered an ideal vehicle for promoting mutual understanding amongst people with different cultures and histories. Students learn to respect each other through the common international language of sport.

The special features of sport make it an excellent way of satisfying the human need for identity reinforcement. This sort of motivation is based on external satisfactions associated mainly with displaying special skills in sports and receiving approval, status, or material rewards for performing well.

In modern societies there is no other institution that gives so many people, regardless of their religion, gender or age, access to a system of social validation and social recognition by others. And social recognition means integration.

Internationally, student-athletes can experience the excitement of World University Championships as well as the Winter and Summer World University Games, the Universiades, the second largest multi-sporting event in the world, second indeed only to the Olympics. These Games provide a tremendous experience both culturally and athletically and are often the platform for student-athletes to launch their international athletic careers.

In this context university sports create an environment which encourages athletically active students to strive for excellence on an academic and sporting level, while giving participants the opportunity to interact socially and competitively. Whilst in the USA student-athletes receive scholarships, the tendency in Europe is towards a growing number of universities offering their student-athletes flexible programmes allowing them to combine study and sport. Therefore the student-athlete's commitment to both the academic and the athletic is recognized, and the values of democracy and sport-for-all are promoted. Next, but just as important, we must consider the:

\section{Health function}

There is no medicine which has so many positive effects as sport does. The health function plays a decisive role in particular in university sports. Students exercise mostly for pleasure and for health benefits. The value of physical activity as part of a healthy lifestyle is irrefutable, and it is a key university sports project to promote, develop, and increasingly integrate physical activity programmes into university life, and thus thereafter into the consciousness of thousands of students, staff and local communities. University sports help to change attitudes, and to get more people more active, more often. Research in many European countries has shown that there is an increasing number of students who, besides their student identity, have an identity as student-athletes. This development means that university sports are an experience of a lifetime and at the same time promote health. Not only will student-athletes get a degree, they will in addition increase their quality of life. Then there is the: 


\section{Economic function}

Sport has developed into big business. Besides the success in sport itself the economic success of sport, or in this case university sports in particular, is of vital importance. Financial resources help to improve the quality of sports and physical activity courses, and, with that, the image of university sports. The commercialisation of university sports seems to be the order of the day and a major trend. This will be discussed in more detail in the context of the perspectives of university sports. One important perspective is the:

\section{Strengthening of the relation to science}

By the relation to science I mean that university sports are innovative, flexible and dynamic due to their orientation to new scientific findings. With inventive opportunities for physical activity reaching from pure recreation to intramurals, and from intermediate levels to highly competitive programmes, university sports are a trendsetter. No other sporting organisation can match the breadth and scope of such a programme. In addition, university student-athletes represent an exciting and vibrant dimension of society.

For that very reason professional management and quality services are necessary. University student-athletes need sports medical support and direct, easy access to therapy and counselling services. In particular competitive programmes need medical, paramedical and psychological support designed for training and competition. So once again, we have interaction between sport and science.

The development of sport, and therefore university sports, goes hand in hand with relevant scientific development. University sports have to make sure they are always up to date regarding the latest theoretical and practical knowledge in this field. On the other hand scientific analysis and evaluation of the physical activity programmes seem to be preconditions for their quality. In university sports newly acquired scientific knowledge is converted into the practical, and practice-oriented activity correlates with scientific findings. Then we have the perspective of:

\section{Professionalisation and cooperation}

And here we will see again the connection between sport and economy. For the further development of university sports strong national and international associations are necessary. Thus the formation of the European University Sports Association 1999 has led to an extremely dynamic development of national university sports associations, and all in all to more rapid intensification of university sports themselves within Europe. The most effective impulses emanating from EUSA aim at better service and prosperity of university sports. The EUSA is one element, albeit an increasingly important one, in the organisational carapace within which members are forced to conduct their activities professionally. In short, the EUSA plays its role in forming and constraining the efforts of national associations.

So professionalisation and cooperation seem to be a permanent commitment. Professionalisation mainly concerns the areas of financial planning, administration, marketing and public relations. Particular attention should be given to cooperation within and between individual university sports associations, and for instance to coordination and communication between the International University Sports Federation and the continental associations.

Cooperation is so important above all because, with the increase of university sports, there seems to be a trend towards the commercialisation mentioned above. Commercialisation means 
adaption of university sports to economic principles. The growing importance of university sports was especially evident this year in Harbin, China, where 200 million people watched the opening ceremony of the Winter Universiade on TV, and this could mean realistic opportunities for intensifying cooperation with both media and economy.

The best example of the relationship between sports and economy is given by the Olympic Games. Due to the commercialisation of the Olympic Games they are now so popular, and the International Olympic Committee has become extremely powerful. Even the U.S. President's efforts failed to influence the IOC's decision to hold the Summer Olympic Games 2016 in Rio!

\section{The identity of university sports}

Regardless of the source of financial and technical support from their institutional, academic, financial or media partners, university sports - their institutions and associations - should be free and independent. Only then can the fascination and positive effects of sport come into being. For instance, let me refer to the positive physical effects such as staying power, strength, mobility, speed and coordination. Not to forget the crucial effects of sport against diseases such as cancer, coronary heart diseases, osteoporosis - to mention only a few - or the psychosocial effects of sport such as

- stress regulation,

- the increase in subjective quality of life due to the effects of sport on social well-being,

- flow-experiences which lead to spontaneous "joie de vivre",

- furthermore, strengthening of self-perception and self-conception is a social by-product of sporting activities.

From a sociological perspective sport is a social phenomenon. Society's values and norms can be seen and experienced in sport more than anywhere else; performance in sport can be reduced to a quantifiable dimension: only goals, seconds, and centimetres count, and so outstanding achievements or records can be understood by everybody. These significant symbols of sport make it appear as an ideal of society. Whereas achievement in other areas remains invisible for many people and can often be appreciated only by experts, in sports success is immediately recognisable and can be understood by one and all.

Sport is one of the few areas in which the individual performance of the human being counts, and it thus fulfils idealistic expectations which can hardly be realised in other institutions of modern societies. It is that charm, often also called "sport appeal", that lies in the overwhelming pleasure in movement itself, and attracts athletes and spectators likewise.

Thus the identity of university sports is to promote sporting activities and sporting values in harmony with the university spirit. University sports have an enormous potential for creating identity for both students and university. Promoting sporting values like fair play - a quality which after all originated in sport - also means giving a new dimension to the university spirit in study, research, and discipline through the strong affirmation of the full humanist development of the individual and, thus, of society at large. This development is not just intellectual, but also moral and physical and gives us a positive perspective for the future.

\section{REFERENCES}

Bundesministerium für Wissenschaft und Forschung (2009). Sportmagazin. Unisport-Special. Wien: Sportverlag 
Canadian Interuniversity Sport (N.N.). Programs and Services. Retrieved June, 1 ${ }^{\text {st }}$, 2010, from http://www.cisport.ca/e/about/index.cfm.

EUSA (2009, September.). European University Sports Newsletter 3/2009. Retrieved June, $1^{\text {st }}, 2010$, from http://www.eusa.eu/files/media_library/newsletter/2009/nl2009_3.pdf.

FISU (N.N.). Fisu History. Retrieved June, 1 ${ }^{\text {st }}, 2010$, from http://www.fisu.net/en/FISU-History-518.html.

FISU (N.N.). Fisu Today. Retrieved June, 1 ${ }^{\text {st }}$, 2010, from http://www.fisu.net/en/FISU-today-517.html (June, 1st, 2010).

University Sport New Zealand (N.N.). About USNZ. Retrieved June, 1 ${ }^{\text {st }}$ 2010, from http://www.universitysport.org.nz/.

University Sport South Africa (N.N.). About us. Overview. Retrieved June, 1 $1^{\text {st }}$, 2010, from http://www.ussa.org.za/loverview.htm.

Weiss, O. (1999). Einführung in die Sportsoziologie. Stuttgart/Wien: UTB und WUV-Universitätsverlag. 